\title{
Further species within Arecaceae (Palmae; Coryphoideae) to non-native flora of Tunisia and North Africa
}

\author{
Ridha El Mokni $i^{1,2,3}$ (1)
}

Key words: Alien flora, Phoenix, Washingtonia, Livistona, Monocots.

\author{
Abstract \\ Five new alien taxa are here recorded from Tunisia. Reported taxa (Livistona \\ chinensis, Phoenix canariensis, P. reclinata, P. theophrasti and Washingtonia robusta) \\ belong to the subfamily Coryphoideae (Arecaceae). Updated nomenclature, brief \\ descriptions, general and national distributions are provided for each species. \\ Livistona chinensis and Phoenix theophrasti are here reported for the first time in \\ North Africa. Identification keys are also provided.

\section{Izvleček} \\ V članku predstavljamo pet novih tujerodnih taksonov iz Tunizije. Vsi zabeleženi \\ taksoni (Livistona chinensis, Phoenix canariensis, P. reclinata, P. theophrasti and \\ Washingtonia robusta) pripadajo poddružini Coryphoideae (Arecaceae). Za \\ vsako vrsto smo prikazali posodobljeno nomenklaturo, kratek opis, splošno \\ in nacionalno razširjenost. Livistona chinensis in Phoenix theophrasti sta prvič \\ zabeleženi v severni Afriki. Predstavili smo tudi določevalne ključe.
}

Phoenix, Washingtonia, Livistona, enokaličnice.

Received: 24. 4. 2020

Revision received: 8. 6. 2020

Accepted: 10. 7. 2020

\footnotetext{
1 Department of Pharmaceutical Sciences "A", Laboratory of Botany, Cryptogamy and plant Biology, Faculty of Pharmacy of Monastir, Avenue Avicenna, 5000-Monastir, University of Monastir, Tunisia. E-mail: ridhaelmokni@yahoo.fr

2 Department of Silvo-pastoral Resources, Laboratory of Silvo-pastoral Resources, Silvo-Pastoral Institute of Tabarka, BP. 345, 8110-Tabarka, University of Jendouba, Tunisia.

3 University of Carthage, Laboratory of Forest Ecology, National Research Institute of Rural Engineering, Water and Forests, Ariana 2080, Tunisia.
} 


\section{Introduction}

The palms, family Arecaceae (Palmae) are one of the most morphologically diverse families in Monocots. Since early molecular and phylogenetic investigations (see e.g., Chase et al. 2000, Stevenson et al. 2000, APG IV 2016), Arecales are most closely aligned with Poales, Commelinales and zingiberales within the Commelinids clade. Morphologically, palms are differentiated from other monocot families by two main characters: a "woody" stipe/stem and leaves that are plicate in bud and segmented (Uhl \& Dransfield 1987). Formal classification of the Araceae recognised six subfamilies that include about 190 genera and ca. 2600 species (Uhl \& Dransfield 1987, 1988, 1999). The Coryphoideae with 45 genera is the second more rich subfamily after Arecoideae (Asmussen et al. 2006) and is characterised by palmate and pinnate leaves with flowers solitary or in sympodial clusters (Uhl \& Dransfield 1987). Genera belong to six tribes, among which Livistona R.Br. (Corypheae tribe), Washingtonia H.Wendl. (Trachycarpeae tribe) and Phoenix L. (Phoeniceae tribe). Species belonging to such genera are perennial climbers, shrubs and trees and distributed across the tropics and warm temperate regions of the world (Stevens 2012).

In Tunisia, palm family consists of two genera (Chamaerops and Phoenix) with three species of which $P$. canariensis is considered cultivated (Dobignard \& Chatelain 2010).

In continuity to ongoing botanical researches aiming at improving the knowledge on the Tunisian vascular flora (see e.g., El Mokni et al. 2015a, 2015b, 2015c, 2019a, 2019b, El Mokni \& Peruzzi 2019, Iamonico \& El Mokni 2018, Domina \& El Mokni 2019, El Mokni 2020, El Mokni et al. 2020) and mainly on Monocots s.lat. (see e.g., El Mokni \& El Aouni 2011, 2012, El Mokni et al. 2010, 2013, 2014, El Mokni 2018a, 2018b, 2018c, El Mokni \& Domina 2018, 2019; El Mokni \& Tison 2018, El Mokni \& Verloove 2017, 2019a, 2019b), five new taxa within Arecaceae (subfamily Coryphoideae) were recorded during field work carried out during the period 2010-2020 from Jendouba (NW-Tunisia), Bizerta and Mannouba (NE-Tunisia), Mahdia, Monastir and Sousse (CE-Tunisia). These recorded five taxa are Livistona chinensis (Jacq.) R.Br. ex Mart., Phoenix canariensis H.Wildpret, $P$. reclinata Jacq., $P$. theophrasti Greuter and Washingtonia robusta H.Wendl.

\section{Materials \& Methods}

Extensive field prospections within central and northern Tunisia (North Africa), mostly between 2010 and 2020, has revealed new national and even North-African re- cords. Records here reported are documented by brief description of each species. The actual status of naturalization for each taxon is assessed based on literature analysis (Pyšek et al. 2004). Taxa identification follows Dowe (2009), Starr et al. (2003), Tutin et al. (1980), Flora of North America (2020) (retrieved from http://www.efloras.org/florataxon.aspx?flora_id=1\&taxon_id=125080), Flora of China (retrieved from http://www.efloras.org/ florataxon.aspx?flora_id=2\&taxon_id=118760), CABI (2020), some additional comments based on the authors' observations of living individuals. Further comments on flowering/fruiting periods, distribution, habitats occupied and field photographs are presented for each newly reported taxon. Identification keys are also given.

Photographed specimens here presented from El Mokni's collection (not online, yet) are used as specimens visa.

The paper is divided in three parts in which taxa (tribus, subtribus -when exist-, genera and species) are arranged in alphabetical sequence. Nomenclature of the taxa presented is mostly in accordance with recent phylogenetic classification of the palm family (see e.g., Dransfield et al. 2005, 2008, Bacon et al. 2012, Baker \& Dransfield 2016) and some databases such as Tropicos (Tropicos 2020), the International Plant Names Index (IPNI 2020) and The Plant List (The Plant List 2020).

\section{Results \& taxonomic notes}

Within Arecaceae, subfamily Coryphoideae, five species (belonging to three genera) and two genera are here added to non-native flora of Tunisia. Among them, one genus (Livistona R.Br.) is here firstly cited for Mediterranean basin and for North Africa, also two species (Livistona chinensis (Jacq.) R. Br. ex Mart., Phoenix theophrasti Greuter) are here reported for the first time in North Africa. An updated key to all the genera of the family is here proposed.

\section{Analytical key of genera within Tunisian Arecaceae}

1. Leaves pinnate, elongate ...............................Phoenix.

1'. Leaves \pm palmate, triangular to rounded .................. 2 .

2. Shrub, leaves triangular fan-shaped, dioecious Chamaerops.

2'. Tree, palmate leav ………………………………..... 3.

3. Petiole split at base; leaf segments filiferous; monoecious. Washingtonia.

3'. Petiole not split at base; leaf segments not filiferous; hermaphroditic

Livistona.

Below are cited new reported taxa with their appropriate tribus and subtribus, when exist. 


\section{Tribe Corypheae Martius in Endlicher, Gen. PI.252. 1837.}

Subtribe Livistoninae Saakov, Palms and Their Culture in the U.S.S.R. 793.1954.

Genus Livistona R. Br., Prodr. Fl. Nov. Holland. 267-268. 1810.

Plants small to large. Stem/stipe solitary, erect, slender, at first covered by persistent leaf sheaths, later becoming bare or covered with persistent petiole bases, ringed conspicuously or obscurely with leaf scars. Leaves palmate or costapalmate, petiole not split at base, strongly armed. Inflorescences axillary within crown of leaves, paniculate with 3-5 orders of branching, about as \pm as long as leaves. Flowers bisexual, borne singly along rachillae. Fruits drupe, blackish, smooth. Seeds globose or ellipsoid.

The genus Livistona R.Br. includes ca. 36 species that have a wide distribution from the Horn of Africa and Southern Arabia to throughout southeastern and eastern Asia, Malesia and Australia (Dransfield et al. 2008, Dowe 2009).

Livistona chinensis (Jacq.) R.Br. ex Mart., Prodr. Fl. Nov. Holland. 268. $1810 \equiv$ Latania chinensis Jacq., Fragm. Bot. 16. t. 11. f. 1. $1801 \equiv$ Saribus chinensis (Jacq.) Blume, Rumphia 2: 48.1838 Eivistona mauritiana Wall. ex Voigt, Hort. Suburb. Calc. 641. $1845 \equiv$ Livistona subglobosa (Hassk.) Mart., Hist. Nat. Palm. 3: 319. 1853.

Hermaphroditic palm with short and stout trunk up to $15 \mathrm{~m}$ tall, $20-30 \mathrm{~cm}$ in diameter, rough with leaf scars. Leaves palmate, petioles to $1.8 \mathrm{~m}$ long, with green or black recurved spines along margins, spines denser proximally, fewer distally on petioles; blades almost circular in outline, 1.2-1.8 m wide, green on both surfaces, regularly divided to $c$. half their length, these split and pendulous at apices. Inflorescences 1-1.2 m long, branched to three orders, light yellow when young and then become green with unpleasant odor, with six or seven partial inflorescences; flowers hermaphroditic, small, sessile in groups of 2-4 flowers, white or yellow, 2-2.5 mm. Fruits green or blue-green, globose to ellipsoid or pyriform, 15-26 mm long, 9-18 mm wide, glossy blue-green to bright green; epicarp ceramic-like (Dowe 2009, Flora of China Editorial Committee 2016).

Flowering period: October to December, Fruiting period: January to February (-March).

Notes on general distribution: L. chinensis is native to Eastern Asia including China, Japan (i.e., Ryukyu Islands, Bonin Islands) and Taiwan (Horikawa 1972, Suzuki 1982, Yoshida et al. 2000, USDA-ARS 2016). The species is widely cultivated as an ornamental and can be found naturalized in the West Indies, tropical America and on many islands in the Indian and Pacific Oceans (Wagner et al. 1999, Meyer et al. 2008, Flora of China Editorial Committee 2016, Govaerts 2016, PIER 2016). L. chinensis is considered invasive in Bermuda (Kairo et al. 2003) and in Mauritius and La Réunion Islands (Moore \& Guého 1984, Strahm 1993, 1999). Within the Mediterranean basin, this taxon seems to be reported only in Portugal and Spain (GBIF database 2020). It is also reported to be growing in riparian forest areas in New Caledonia (Hequet et al. 2009). No records were made up till now for North Africa (see e.g., Govaerts 2020, APD 2020).

Occurrence in Tunisia (Figure 1) and casual status: Tunisian plants grow within sidewalks near a private garden, in the government of Monastir. Since the taxon was found only at one locality, with one mature individual and more than 30 juvenile seeds germinations were observed, and this appears to be an occasional resulting from the use of imported seed mixtures for gardening purposes. According to Pyšek et al. (2004), and Richardson \& Pyšek (2006) Livistona chinensis is evaluated as casual in Tunisia.

Specimina Visa: TUNISIA: Monastir (MonastirCity), sidewalks near a private garden, $35^{\circ} 46^{\prime} 02^{\prime \prime} \mathrm{N}$, 010 49' 53" E, 15 m a.s.l., 14 February 2019, El Mokni (photos).

\section{Tribe Trachycarpeae Satake, Hikobia 3:121. 1962.}

Genus Washingtonia H.Wendl., Bot. Zeitung (Berlin) 37(5): 68. 1879.

Plants tree palms. Stems solitary, erect, tall, partly or completely covered with old leaf bases and marcescent dry leaves forming conspicuous skirt around trunk. Leaves: sheath fibers soft; petiole split at base, conspicuously armed with teeth along margins; blade costapalmate; plication induplicate; segments lanceolate, basally connate, bearing fibers between segments. Inflorescences axillary within crown of leaves, paniculate, arching well beyond leaves, with 2 orders of branching. Flowers bisexual, short- pedicellate. Fruits drupes, blackish.

The genus Washingtonia H.Wendl. is made up of two species native to the southwestern United States (in southern California, southwest Arizona, (Nevada) Texas) and northwest Mexico (in northern Baja California and Sonora) (Jones 1995). Washingtonia filifera (Linden ex André) H.Wendl. ex De Bary and W. robusta H. Wendl. (Oppenheimer \& Bartlett 2002). There are also hybrids between the two, which are sometimes referred to as $W$. $\times$ filibusta Hort. ex Hodel. (Hodel 2014). Both species were commonly cultivated across the southern United States, the Middle East, southern Europe, and North Africa. 
- Hacquetia 20/1 •2021, 19-32

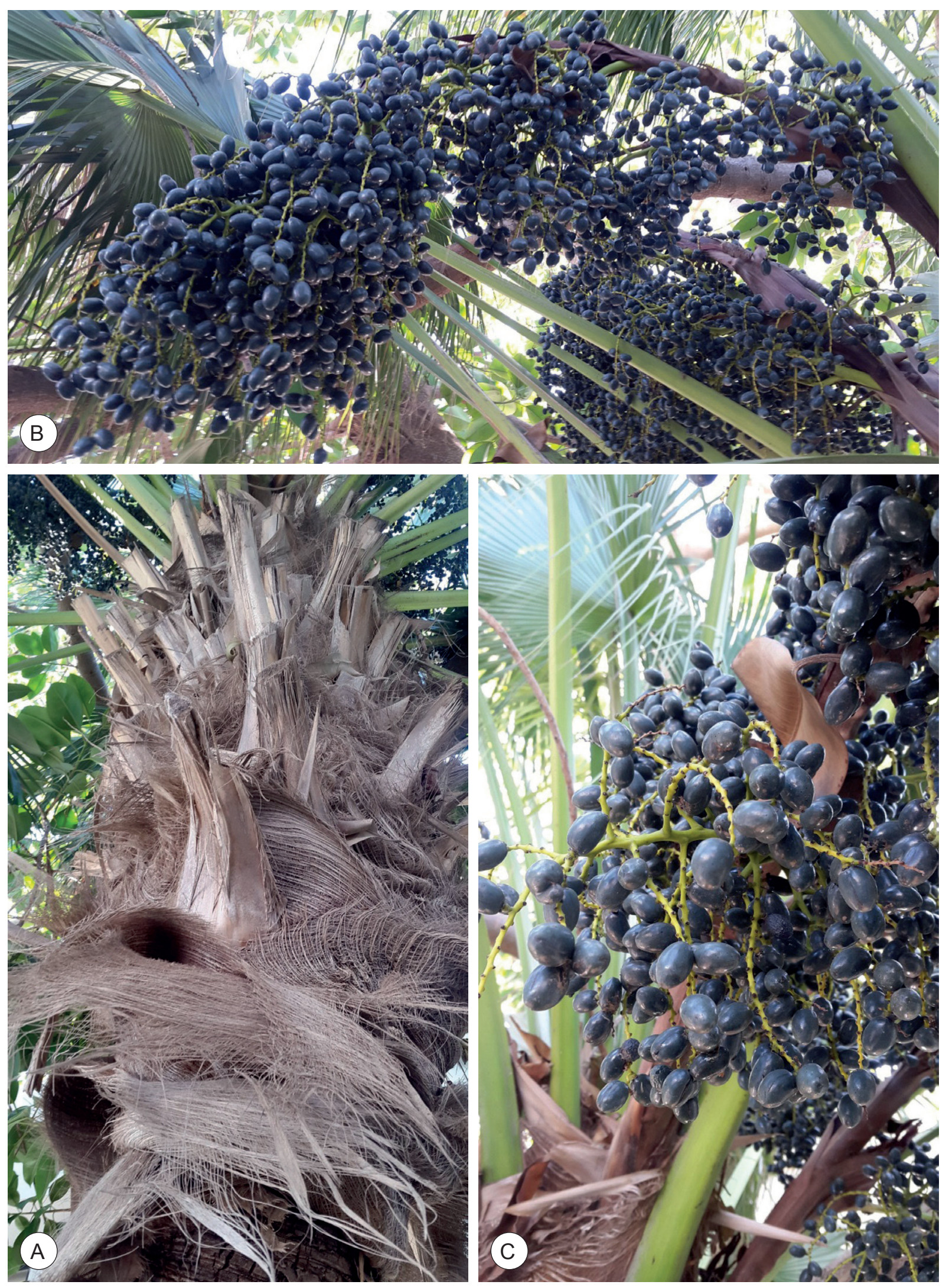


Washingtonia robusta $\mathrm{H}$.Wendl. Berliner Allg. Gartenzeitung 2: 198. 1883 三Neowashingtonia robusta (H.Wendl.) A.Heller. Cat. N. Amer. Pl.: 3. $1898 \equiv$ Pritchardia robusta (H.Wendl.) Schröt.Schweiz. Gartenbau 7: 8. 1931 .

Monoecious, self-compatible, fast growing palm with a slender trunk that gradually tapers from ground level to the crown ( 15 to $20 \mathrm{~m}$ high and 0.6 to $1.2 \mathrm{~m}$ in diameter). Leaves with 40 to 60 segments, divided nearly to middle of frond and attached to the tree with a $1.2-1.5 \mathrm{~m}$ long plano-convex petiole. Red brown petioles exhibit curved spines on their entire length. Tubular, creamy pink flowers are borne in panicles up to $3 \mathrm{~m}$, bearing numerous small, white bisexual flowers in compound clusters. Fruits small black, ovoid-oblong to spherical drupes (Brickell \& Zuk 1997, Turner \& Wasson 1997, Broschat 2017, Bailey 1936, Felger \& Joyal 1999, Brown \& Brown 2012).

Flowering period: June to August, Fruiting period: September to November (-December).

Notes on general distribution: Washingtonia robusta is native to the arid regions in northwest mainland Mexico (McCurrach 1960, Jones 1995) and the Baja California where it may have originated (Cornett 1989) and where it is still widespread (Fonseca 1999, Minnich et al. 2011). It is also on record for the Sonora Desert in both Mexico and Southern California (Felger \& Joyal 1999, Minnich et al. 2011). Distributed globally as a horticultural plant (Spennemann 2018), Washingtonia robusta is regarded as naturalized beyond its natural range in Southern California (Cornett et al. 1986), Southern Florida (Institute for Regional Conservation 2016), Reunion Island (Indian Ocean) (Meyer et al. 2008), the North Island of New Zealand (Martin 2009), and parts of Hawaii (Oppenheimer \& Barlett, 2002, Starr et al. 2003). Within Europe and the Mediterranean basin, the plant is reported in Portugal, Spain, France, Italy, Sardegna (see e.g., Verloove 2013, APD 2020, GBIF database 2020). In North Africa, the taxon is reported only in Canary Islands and Algeria (see e.g., Acebes Ginovés et al. 2004, Zeddam \& Raus 2016, APD 2020).

Occurrence in Tunisia (Figure 2) and status of naturalization: Tunisian plants from seedlings germination of Washingtonia robusta found in many localities occur usually in small number of scattered individuals along sidewalks and near agglomerations, where the plant was introduced. Moreover, small populations have also been observed, especially along the metro railways (Sousse towards Mahdia) and in the surrounding of "Lac Tunis" where the most large population is reported with more than 60 mature individuals (up to $5 \mathrm{~m}$ high) within an area of about 1 ha. According to Pyšek et al. (2004) criteria and categorisation, Washingtonia robusta can be considered as a naturalized alien species in Tunisia.

Taxonomic notes: Washingtonia robusta can be distinguished from $W$. filifera by its thinner and taller trunk. Lower leaves persist on the tree after they die, forming a dense, brown, shaggy covering below the living, bright green, broad, fanshaped leave with hairy filament. In addition, Stalk of the leaves is spiny and shorter than W. filifera (Brickell \& Zuk 1997, Oppenheimer \& Bartlett 2002).

Specimina Visa: TUNISIA: Monastir, Monastir-City, roadsides and sidewalks and as epiphytic on Phoenix canariensis $\mathrm{H}$. Wildpret, 354' 02" N, 010 49' 55" E, 15 m a.s.l., 23 January 2017, El Mokni (photos); Bizerta, Bizerta-City, in abandoned fields, 37 $16^{\prime} 07^{\prime \prime} \mathrm{N}$, $009^{\circ}$ 51' 28" E, $10 \mathrm{~m}$ a.s.l., 26 July 2017, El Mokni (photos); Mahdia, near railways station, 35 29' 48" N, $011^{\circ} 03^{\prime} 38^{\prime \prime} \mathrm{E}, 2 \mathrm{~m}$ a.s.l., 25 January 2020, El Mokni (photos); Manouba, surrounding "Lac Tunis", near Moncef Bey station, 36 47' 31" N, 010 11' 35" E, 1 m a.s.1., 05 October 2016, El Mokni (photos).

\section{Tribe Phoeniceae Drude in Martius, Fl. Brasil. 3(2): 279. 1881.}

Genus Phoenix L., Sp. Pl.2:1188. 1753; Gen. Pl. ed. 5. 496. 1754

Stems solitary or clustered, erect or ascending often clothed in old leaf bases. Leaves sheath fibers soft; petiole not split at base, armed; blade pinnate; plication induplicate; segments lanceolate, in 1 or more planes; basal segments modified into stout spines. Inflorescences in pedunculate spadices, with few, simple branches, axillary within crown of leaves, paniculate, ascending, much shorter than leaves, with 1 order of branching; spathe 1 . Dioecious, flowers yellowish; staminate flowers borne singly along rachillae. Pistillate flowers borne singly on rachillae. Fruits drupes, berrylike, fleshy; exocarp blackish brown, smooth. Seed one, elongate, deeply grooved along ventral side (Tutin et al. 1980).

$\longleftarrow$ Figure 1: Livistona chinensis in Tunisia. A: Stem/stipe solitary, erect, slender, covered by persistent leaf sheaths; B: Infrutescences axillary within crown of leaves, paniculate with 3-5 orders of branching, about as long as leaves in fruiting period; C: Fruits glossy blue-green; epicarp ceramiclike. Photos by Ridha El Mokni (14. 02. 2019).

Slika 1: Livistona chinensis v Tuniziji. A: posamezno steblo, pokončno, vitko, prekrito z ostanki listov; B: soplodje je znotraj krošnje listov aksilarno, 3-5 krat razvejano, približno tako dolgo, kot listi v času plodenja; C: sijoči modro-zeleni plodovi; epikarp je "keramičast”. Fotografije Ridha El Mokni (14.02. 2019). 
- Hacquetia 20/1 • 2021, 19-32
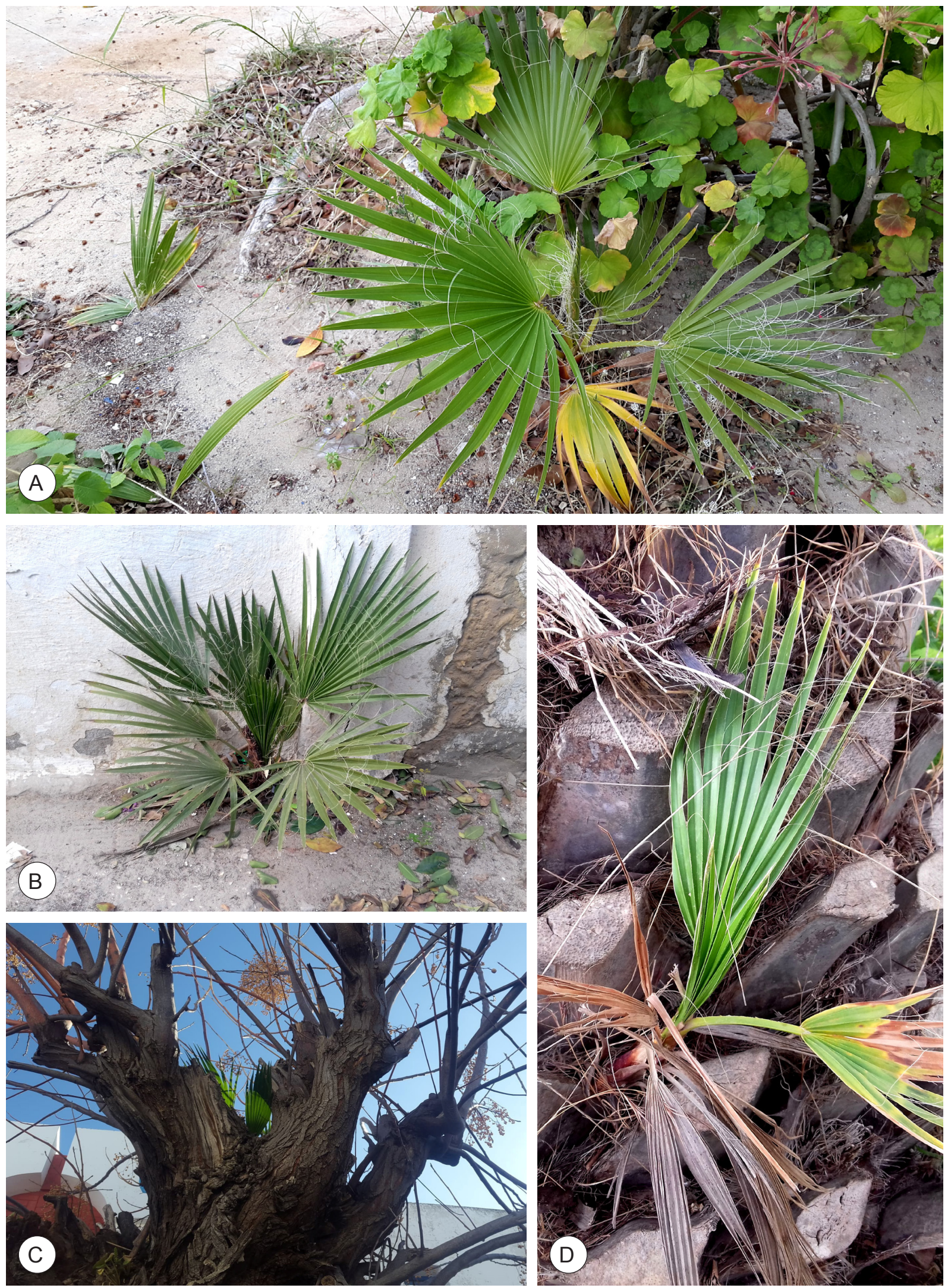
The genus Phoenix L. includes 14 species (Govaerts \& Dransfield 2005) traditionally distributed in the Old World from the Canary and Cape Verde islands in the Atlantic Ocean, throughout Africa, Madagascar and Asia, reaching Sumatra, Taiwan and the Philippines in the East (Barrow 1998, Dransfield et al. 2008).

In Tunisia, the genus was represented only by one species $(P$. dactylifera $\mathrm{L}$.), we here reported the occurrence of three more non-native species. An update analytical key for all species is here proposed.

\section{Analytical key for Tunisian species belonging to the} genus Phoenix L.

1. trunk multiple P. reclinata.

1'. trunk solitary.... ... 2.

2. Fruits $25-75 \mathrm{~mm}$; P. dactylifera.

2'. Fruits $14-23 \mathrm{~mm}$; ... 3.

3. Fruits $15-23 \mathrm{~mm}$; mesocarp succulent, orange to dark purple P. canariensis.

3'. Fruits $14-16 \mathrm{~mm}$; mesocarp fibrous, yellowish-brown to blackish P. theophrasti.

1.Phoenix canariensis H.Wildpret, Prov. Agric. Hort. Ill. 2: 293-295, fig. 67-68. Oct. 1882, nom. cons.

Dioecious large palm up to $18 \mathrm{~m}$ tall, with a thick erect trunk up to $1.2 \mathrm{~m}$ in diameter and a crown occupying the upper $2.5-4.5 \mathrm{~m}$. Leaves up to $1.5-1.8 \mathrm{~m}$ long are alternate and pinnately compound, containing lanceolate leaflets $30-45 \mathrm{~cm}$ long with sharp spines $5-8 \mathrm{~cm}$ long on the lower half of the petiole. Flowers creamy yellowwhite and open from a husk-like structure that appears periodically throughout the year. Fruit elliptical fleshy drupe, 1-3 cm long, occurring in hanging clusters, each containing a single large seed, mesocarp orange-brown to dark purple (Gilman \& Watson 1994).

Flowering period: March to April, Fruiting period: May to July.

Notes on general distribution: Phoenix canariensis is native to Canary Islands (Santos Guerra 1994, Morici 1998). It was introduced to mainland Europe from the 1600s, and around the Mediterranean including North Africa and West Asia, and was introduced across the Atlantic Ocean from as early as the 1700 s as an ornamental palm, first by Spanish missionaries and colonizers, such as to California, Central and South America. It has since then been widely introduced as a popular ornamental palm, to parts of Australasia, Asia and Africa (CABI 2020). It has recently been noted naturalizing and becoming invasive in southern California (DiTomaso \& Healy 2006, Cal-IPC 2006) and northern New Zealand, mostly in riverine wetland and coastal habitats (Esler \& Astridge 1987). Planted widely, seeds are eaten and spread by birds (DiTomaso \& Healy 2006). Within the Mediterranean basin, the taxon is mainly reported in the Iberic peninsula, France and Italy (GBIF database 2020). In North Africa, the species was cited only for Morocco and Algeria with no records made up till now for Tunisia (see e.g., APD 2020, GBIF database 2020).

Occurrence in Tunisia (Figure 3) and status of naturalization: we found juvenile individuals of Phoenix canariensis in many Tunisian localities (within Ariana, Bizerta, Jendouba, Mahdia, Monastir, Sousse) along sidewalks and near agglomerations as epiphytic on Melia azedarach L., where the plant was introduced since more than 50 years ago. Hence this ornamental palm can produce a dense mat of seedlings, that can thrive in a variety of habitats and soil types, and can tolerate high temperatures and salt winds, more than 300 individuals in different ages were reported during the last two years between Sousse and Mahdia Cities, along the metro railways. According to Pyšek et al. (2004) criteria and categorisation, Phoenix canariensis can be considered as a naturalized alien species in Tunisia.

Specimina Visa: TUNISIA: Ariana, roadsides and sidewalks, $36^{\circ} 49^{\prime} 39^{\prime \prime} \mathrm{N}, 010^{\circ} 10^{\prime} 57^{\prime \prime} \mathrm{E}, 10 \mathrm{~m}$ a.s.l., 23 December 2014, El Mokni (photos); Bizerta, roadsides and sidewalks as epiphytic on Melia azedarach L., $37^{\circ} 16^{\prime} 15^{\prime \prime} \mathrm{N}, 009^{\circ} 52^{\prime} 31^{\prime \prime} \mathrm{E}, 5 \mathrm{~m}$ a.s.l., 20 January 2019, El Mokni (photos); Jendouba, roadsides and sidewalks, $36^{\circ} 30^{\prime} 03^{\prime \prime} \mathrm{N}, 008^{\circ} 47^{\prime} 04^{\prime \prime} \mathrm{E}, 145 \mathrm{~m}$ a.s.l., 11 October 2008, El Mokni (photos); Mahdia towards Sousse, along the metro railways, Sidi-Mesaoud $35^{\circ} 31^{\prime} 15^{\prime \prime} \mathrm{N}$, $011^{\circ} 01^{\prime} 37^{\prime \prime}$ E, $25 \mathrm{~m}$ a.s.l., 04 April 2019, El Mokni (photos); Moknine-Gribaâ 35 38' 12" N, 010 54' 29" E, $20 \mathrm{~m}$ a.s.l., 04 April 2019, Sahline $35^{\circ} 45^{\prime} 41^{\prime \prime} \mathrm{N}$, $010^{\circ} 41^{\prime} 46^{\prime \prime}$ E, 20 m a.s.l., 04 April 2019; Sousse, roadsides and sidewalks, $35^{\circ} 46^{\prime} 05^{\prime \prime} \mathrm{N}, 010^{\circ} 38^{\prime} 34^{\prime \prime} \mathrm{E}, 5 \mathrm{~m}$ a.s.l., 04 April 2019, El Mokni (photos); Monastir-City,

— Figure 2: Washingtonia robusta in Tunisia. A: different juvenile plants from seedling within a public garden (Monastir, CE Tunisia; 29. 12. 2018); B: habit of a vigorous plant from seedling under old walls (Monastir-City, CE Tunisia; 23. 01. 2017); C: juvenile plant from seedling as epiphytic on Melia azedarach (Bizerta-City, NE Tunisia; 09. 02. 2020); D: juvenile plant from seedling as epiphytic on Phoenix canariensis (Sousse, CE Tunisia; 19. 05. 2018). Photos by Ridha El Mokni.

Slika 2: Washingtonia robusta v Tuniziji. A: različne mlade rastline v javnem vrtu (Monastir, CE Tunizija; 29. 12. 2018); B: izgled vitalne rastline pod starimi zidovi (Monastir-City, CE Tunizija; 23. 01. 2017); C: mlada rastlina iz sadike kot epifit na vrsti Melia azedarach (Bizerta-City, NE Tunizija; 09. 02. 2020); D: mlada rastlina iz sadike kot epifit na vrsti Phoenix canariensis (Sousse, CE Tunizija; 19. 05. 2018).

Fotografije Ridha El Mokni. 
- Hacquetia 20/1 • 2021, 19-32

Ridha El Mokni

Further species within A

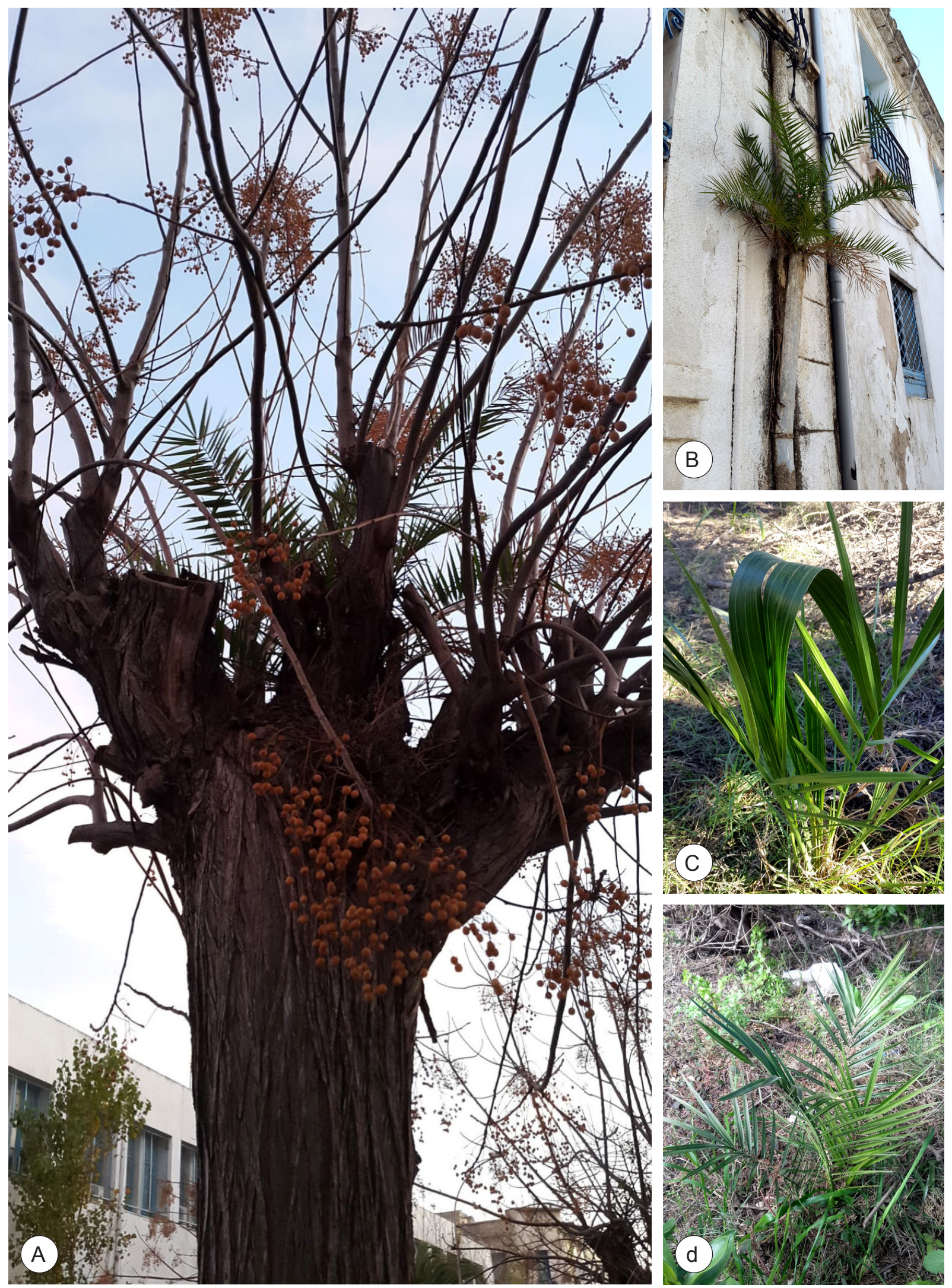


roadsides and sidewalks, public gardens $35^{\circ} 45^{\prime} 56^{\prime \prime} \mathrm{N}$, $010^{\circ} 49^{\prime} 49^{\prime \prime}$ E, 15 m a.s.l., 04 December 2018, El Mokni s.n. (Personal Herbarium of Ridha El Mokni at the Faculty of Pharmacy of Monastir).

2.Phoenix reclinata Jacq. Fragm. Bot. 1: 27. t. 24. $1800 \equiv$ Phoenix leonensis Lodd. ex Kunth. Enum. Pl. 3: 257. 1841.

Dioecious clustering palm, variable in shape and form but tends to grow as clumps composed of multiple stems from 7.5 to $15 \mathrm{~m}$ in height and $30 \mathrm{~cm}$ in width. Leaves pinnate (bright to deep green in color) with a prounced sideways curve, growing 2.5 to $4.5 \mathrm{~m}$ in length and $75 \mathrm{~cm}$ in width, petioles with long, sharp spines at the base. Crown with 20 to 40 leaves. Staminate inflorescence erect; prophyll green-yellow in bud, strongly 2-keeled, coriaceous; rachis $17-30 \mathrm{~cm}$. Staminate flowers creamy-white; calyx cupule $1 \mathrm{~mm}$ high; petals with apex acute-acuminate in shape and with jagged margins, 3 (rarely 4), 6-7 × $-3 \mathrm{~mm}$. Pistillate inflorescence erect, arching with weight of fruits; prophyll as for staminate inflorescence; peduncle green-yellow turning orange-brown, becoming pendulous on fruit maturity, to $60-1.5 \mathrm{~cm}$. Fruits ovoid-ellipsoid or almost obovoid orange in color, $13-20 \times 7-13 \mathrm{~mm}$, mesocarp sweet, about $1-2 \mathrm{~mm}$ thick. Seed obovoid, with rounded apices (cf. Barrow 1998).

Flowering period: August to October, Fruiting period: February to April.

Notes on general distribution: Phoenix reclinata is indigenous to the semi-arid plains of Senegal, and occurs throughout tropical and subtropical Africa, northern and southwestern Madagascar and the Comoro Islands. It occurs naturally along the eastern seaboard of Africa, extending into Egypt (see e.g., Pooley 1993, APD 2020). P. reclinata is mainly riverine in distribution, where the root system plays an important part in bank stabilization, and occurs also in the brackish-water regions adjacent to mangrove forests (Wicht 1969), but it also grows in open savannah. Within the Mediterranean basin, this taxon seems to be reported only in Spain (GBIF database 2020). No records were made up till now for North Africa except from Algeria (GBIF database 2020).

Occurrence in Tunisia (Figure 4. A \& B) and casual status: Tunisian plants grow within sidewalks near a public garden, in the government of Monastir. Since the taxon was found only at one locality, with one mature 3 -stemmed individual and more than 20 juvenile seedlings, and this appears to be an ornamental tree resulting from the use of imported plants for gardening purposes. Phoenix reclinata is here evaluated as casual in Tunisia (Pyšek et al. 2004, Richardson \& Pyšek 2006).

Specimina Visa: TUNISIA: Monastir (MonastirCity), margins of a private garden, $35^{\circ} 46^{\prime} 47^{\prime \prime} \mathrm{N}$, $010^{\circ} 48^{\prime} 59^{\prime \prime}$ E, 15 m a.s.l., 04 January 2019, El Mokni (photos).

\section{Phoenix theophrasti Greuter, Bauhinia 3: 243. 1967.}

Dioecious palm that has a clustering stem and can grow up to 15 meters. Leaves paripinnate (3-5 m long), obliquely vertical bluish-colored are composed of smaller, shorter and thicker leaflets compared to $P$. dactylifera. The tips of the leaflets are pointed and very sharp. Flowers in composite panicles, pedicel length grows to $30 \mathrm{~cm}$ in female plants which is twice as long as in the male plant. Fruits elliptical berries (12-16 mm long), mesocarp brownish yellow then black, soft, and edible (cf. Barrow 1998).

Flowering period: April to May, Fruiting period: September to October.

Notes on general distribution: Phoenix theophrasti is a rare endemic to the Aegean region. It was first discovered on the island of Crete (Greuter 1967). It was known only from coastal localities in Crete where the main occurrence being at Vai on the east coast (Barclay 1974, Anon. 1983). Its endemic area was extended by the continuous discoveries of the occurrence of occasional specimens within ten stands on Crete and nearby islands. It was then discovered in further northeast with the new sites on the Datça Peninsula of Turkey (Boydak 1983, 1985, Boydak \& Yaka 1983). No more records were made up till now neither within the Mediterranean basin nor in North Africa (GBIF database 2020).

Occurrence in Tunisia (Figure 4. C) and casual status: Tunisian plants grow within a rocky coastal, in the government of Jendouba. Since the taxon was found only at one locality, with one mature 3-stemmed individual and more than 20 juvenile seedlings, and this appears to be an ornamental tree resulting from the use of imported plants for gardening purposes. Phoenix theophrasti is here evaluated as casual in Tunisia (Py̌sek et al. 2004, Richardson \& Py̌sek 2006).

— Figure 3: Phoenix canariensis in Tunisia. A: juvenile plant from seedling as epiphytic on Melia azedarach (Bizerta-City, NE Tunisia; 09. 02. 2020); B: juvenile plant from seedling on a roof water pipe (Bizerta-City, NE Tunisia;15. 09. 2018); C \& D: two different stages of juvenile plants growing within public gardens (Monastir, CE Tunisia; 25. 06. 2017). Photos by Ridha El Mokni.

Slika 3: Phoenix canariensis v Tuniziji. A: mlada rastlina kot epifit na vrsti Melia azedarach (mesto Bizerta, SV Tunizija; 09. 02. 2020); B: mlada rastlina na žlebu (mesto Bizerta, SV Tunizija; 15. 09. 2018); C \& D: dve različni fazi mladih rastlin, ki uspevajo v javnih vrtovih (Monastir, CE Tunizija; 25. 06. 2017). Fotografije Ridha El Mokni. 
- Hacquetia $20 / 1 \cdot 2021,19-32$
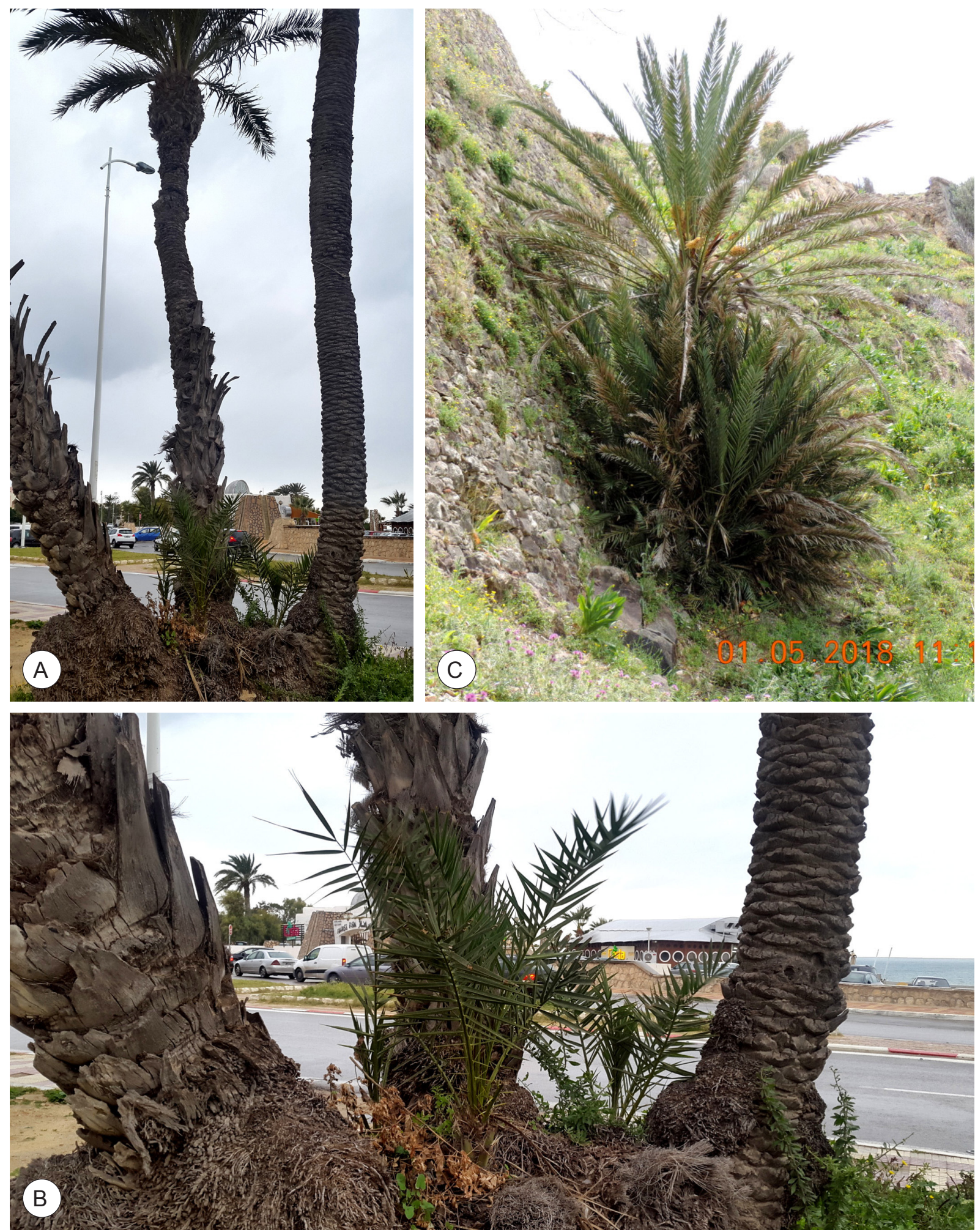

Figure 4: A \& B: Phoenix reclinata in the margin of a public garden within Monastir region (CE Tunisia; 04. 01. 2019); C: Phoenix theophrasti in wild within Tabarka region (NW Tunisia; 01. 05. 2018). Photos by Ridha El Mokni.

Slika 4: A \& B: Phoenix reclinata na robu parka na območju mesta Monastir (CE Tunis; 04. 01. 2019); C: Phoenix theophrasti v naravi na območju Tabarka (SZ Tunizija; 01. 05. 2018). Fotografije Ridha El Mokni. 
Taxonomic notes: Main distinctive characters of Phoenix theophrasti Greuter (vs $P$. dactylifera L.) are i) fruits not very elongated and rounded at the ends, ii) the presence of large thorns, iii) the large diameter of its stipe up to 50 $\mathrm{cm}$, and iv) the systematic presence of shoots at its base as well as at mid-height.

Specimina Visa: TUNISIA: Jendouba, Tabarka, in a restricted rocky coastal locality within Anthyllis barbajovis L. communities, $36^{\circ} 57^{\prime} 48^{\prime \prime} \mathrm{N}, 008^{\circ} 45^{\prime} 23^{\prime \prime} \mathrm{E}, 5$ m a.s.l., 01 May 2018, El Mokni (photos).

\section{References}

Acebes Ginovés, J. R., del Arco Aguilar, M., García Gallo, A. León Arencibia, M. C., Pérez de Paz, P. L., Rodríguez Delgado, O., Wildpret de la Torre, W., Martín Osorio, V. E., Marrero Goméz, C. \& Rodríguez Navarro, L. 2004: Pteridophyta, Spermatophyta. In: Izquierdo, I., Martín, J. L., Zurita, N. \& Arechavaleta, M. (ed.), Lista de especies silvestres de Canarias (hongos, plantas y animales terrestres). Gobierno de Canarias, La Laguna, pp. 96-143.

Anon. 1983: Phoenix theophrasti Greuter. Red Data Sheet (1983 version). Kew. IUCN Threatened Plants Committee.

APD. 2020: African Plant Database (version 3.4.0). Livistona chinensis (Jacq.) R.Br., Phoenix canariensis H.Wildpret, Phoenix reclinata Jacq. and Washingtonia robusta H.Wendl. - Conservatoire et Jardin botaniques; South African National Biodiversity Institute, Pretoria, Genève, viewed on 04 April 2020, from http://www.ville-ge.ch/

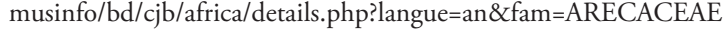

APG IV. [Angiosperm Phylogeny Group IV] 2016: An update of the Angiosperm Phylogeny Group classification for the orders and families of flowering plants. Botanical Journal of the Linnean Society 181: $1-420$.

Asmussen, C. B., Dransfield, J., Deickmann, V., Barfod, A. S., Pintaud, J. C. \& Baker, W. J. 2006: A new subfamily classification of the palm family (Arecaceae): evidence from plastid DNA phylogeny. Botanical Journal of the Linnean Society 151: 15-38.

Bacon, C. D., Baker, W. J. \& Simmons, M. P. 2012: Miocene dispersal drives island radiations in Trachycarpeae (Arecaceae/Palmae). Systematic Biology 61: 426-442. DOI: https://doi.org/10.1093/sysbio/syr123

Bailey, L. H. 1936: Washingtonia. Gentes Herbarum 4 (3): 51-82.

Baker, W. J. \& Dransfield, J. 2016: Beyond Genera Palmarum: progress and prospects in palm systematics. Botanical Journal of the Linnean Society 182: 207-233. DOI: https://doi.org/10.1111/boj.12401

Barclay, C. 1974: A new locality of wild Phoenix in Crete. Annales Musei Goulandris 2: 23-29.

Barrow, S. C. 1998: A Monograph of Phoenix L. (Palmae: Coryphoideae). Kew Bulletin 53 (3): 513-575.

Boydak, M. \& Yaka, M. 983: Datça Hurmasi (Phoenix theophrasti Greuter) ve Datça Yarlmadasmda saptanan dogal yayihsi. Istanbul Univ. Orman Fakültesi dergisi, 4, 33: 73-92.

Boydak, M. 1983: Ülkemizin nadide bir dogal türü Datça Hurmasi (Phoenix theophrasti Greuter). Istanbul. Çevre Koruma 18: 20-21.
Boydak, M. 1985: The Distribution of Phoenix theophrasti in the Datça Peninsula, Turkey. Biological Conservation 32:129-135.

Brickell, C. \& Zuk, J. D. 1997: The American Horticultural Society A-Z Encyclopedia of Garden Plants. DK Publishing, Inc., NY.

Broschat, T. K. 2017: Washingtonia robusta: Mexican Fan Palm (Vol. EH-827). Miami: Environmental Horticulture Department UF/IFAS Extension.

Brown, A. \& Brown, D. 2012: Washingtonia robusta - The Mexican, Skyduster, or Petticoat Palm, viewed on 06 April 2020, from https:// www.hardytropicals.co.uk/Palms/Washingtonia_robusta.php

CABI. 2020: Phoenix canariensis. In: Invasive Species Compendium. Wallingford, UK: CAB International. www.cabi.org/isc

Cal-IPC, 2006: California Invasive Plant Council. http://www. cal-ipc.org/

Chase, M. W., Soltis, D. E., Soltis, P. S., Rudall, P. J., Fay, M. F., Hahn, W. J., Sullivan, S., Joseph, J., Givnish, T. J., Sytsma, K. J. \& Pires, J. C. 2000: Higher-level systematics of the monocotyledons: An assessment of current knowledge and a new classification. Pages 3-26. In: Wilson K. L. \& Morrison D. A., ed.: Systematics and evolution of monocots. CSIRO, Collingwood, Australia.

Cornett, J. W., Stewart, J. \& Glenn, Th. 1986: Washingtonia robusta Naturalized in Southeastern California. Bulletin of the Southern California Academy of Sciences 85 (1): 56-57.

DiTomaso, J. \& Healy, E. A. 2006: Weeds of California and Other Western States. UC DANR Publ. \#3488

Dobignard, A. \& Chatelain, C. 2010 : Index synonymique de la flore d'Afrique du Nord, vol. 1 : Pteridophyta, Gymnospermae, Monocotyledoneae, Genève, Ville de Genève - Éditions des Conservatoire et Jardin Botaniques, pp. 88-89.

Domina, G. \& El Mokni, R. 2019: An inventory of the names of vascular plants endemic to $\mathrm{C}$ Mediterranean and described from Tunisia. Phytotaxa 409 (3): 105-128. DOI: https://doi.org/10.11646/ phytotaxa.409.3.1.

Dowe, J. L. 2009: A taxonomic account of Livistona R.Br. (Arecaceae). Gardens' Bulletin 60 (2):185-344.

Dransfield, J., Uhl, N. W., Asmussen, C. B., Baker, W. J., Harley, M. M. \& Lewis, C. E. 2005: A new phylogenetic classification of the palm family, Arecaceae. Kew Bulletin 60: 559-569.

Dransfield, J., Uhl, N. W., Asmussen, C. B., Baker W. J., Harley, M. M. \& Lewis, C. E. 2008: Genera Palmarum: the evolution and classification of palms. Richmond (VA): Kew Publishing.

El Mokni, R. \& Domina, G. 2018: Spirodela polyrhiza (L.) Schleid., Wolffia arrhiza (L.) Wimm. - Pp.197-198 in Raab-Straube E. von \& Raus Th. (ed.) 2018: Euro+Med-Checklist Notulae, 9 [Notulae ad floram euromediterraneam pertinentes No. 38]. Willdenowia 48: 195-220. DOI: https://doi.org/10.3372/wi.48.48203

El Mokni, R. \& Domina, G. 2019: Taxonomic and distributive notes on Serapias lingua subsp. tunetana (Orchidaceae), a rare endemic to Tunisia. Collectanea Botanica 38: e005. DOI: https://doi. org/10.3989/collectbot.2019.v38.005

El Mokni, R. \& El Aouni, M. H. 2011: Découverte de Sparaxis tricolore, Sparaxis tricolor (Curt.) Ker-Gawl. (Iridaceae Juss.) pour la flore de Tunisie : une adventice naturalisée. Le Monde des Plantes 505: 11-14. 
El Mokni, R. \& El Aouni, M. H. 2012: Zantedeschia aethiopica (Araceae) a new species naturalized in the Northwest of Tunisia. Flora Mediterranea 22: 191-196.

El Mokni, R. \& Peruzzi, L. 2019: Rediscovery and conservation of Linaria cossonii Bonnet \& Barratte (Plantaginaceae) in Tunisia. Phytotaxa 423 (5): 284-288. DOI: https://doi.org/10.11646/ phytotaxa.423.5.2

El Mokni, R. \& Tison, J. M. 2018: Allium litardierei J.-M. Tison - Pp. 196-197 in Raab-Straube E. von \& Raus Th. (ed.) 2018: Euro+MedChecklist Notulae, 9 [Notulae ad floram euromediterraneam pertinentes No. 38]. Willdenowia 48: 195-220. DOI: https://doi.org/10.3372/ wi. 48.48203

El Mokni, R. \& Verloove, F. 2017: Ehrharta calycina Sm.- Pp. 299 in: Raab-Straube E. von \& Raus Th. (ed.) 2017: Euro+Med-Checklist Notulae, 8 [Notulae ad florameuro-mediterraneam pertinentes No. 37]. Willdenowia 47: 293-309.

El Mokni, R. \& Verloove, F. 2019a: New records, distribution and taxonomic notes for non-native vascular flora of Tunisia - I. Poaceae. Flora Mediterranea 29: 45-53.

El Mokni, R. \& Verloove, F. 2019b: Cyperus alternifolius subsp. flabelliformis Kük. - Pp. 430-431 in: Raab-Straube E. von \& Raus Th. (ed.), Euro+Med-Checklist Notulae, 11 [Notulae ad floram euromediterraneam pertinentes No. 40]. Willdenowia 49: 421-445. DOI: https://doi.org/10.3372/wi.49.49312

El Mokni, R. 2018a: Serapias $\times$ debelairii, a new natural hybrid from Tunisia within a sympatric population of $S$. stenopetala and S. parviflora. Journal Europäischer Orchideen 50 (1): 67-80.

El Mokni, R. 2018b: Dipcadi fulvum (Cav.) Webb \& Berthel. Pp.198-199 in Raab-Straube E. von \& Raus Th. (ed.) 2018: Euro+Med-Checklist Notulae, 9 [Notulae ad floram euromediterraneam pertinentes No. 38]. Willdenowia 48: 195-220. DOI: https:// doi.org/10.3372/wi.48.48203

El Mokni, R. 2018c: Tradescantia fluminensis Vell., Tradescantia pallida (Rose) D. R. Hunt- Pp.199-200 in Raab-Straube E. von \& Raus Th. (ed.) 2018: Euro+Med-Checklist Notulae, 9 [Notulae ad floram euromediterraneam pertinentes No. 38]. Willdenowia 48: 195-220. DOI: https://doi.org/10.3372/wi.48.48203

El Mokni, R. 2020: Echinophora spinosa L. (Apiaceae), a new species in the flora of Tunisia and second report from North Africa. Hacquetia 19/1: 137-142.

El Mokni, R., Amari, D. \& El Aouni, M. H. 2013: Two varieties of Ophrys apifera (Orchidaceae) new to North Africa. Journal Europäischer Orchideen 45 (1): 77-89.

El Mokni, R., De Belair, G. \& Domina, G. 2019a: Lectotypification of the name Scrophularia tenuipes Coss. (Scrophulariaceae). Phytotaxa 399: 167-169. DOI: https://doi.org/10.11646/phytotaxa.399.2.7

El Mokni, R., Domina, G., Sebei, H. \& El Aouni, M. H. 2015c: On the distribution and subspecific variation of the Tunisian-Algerian endemic Delphinium sylvaticum Pomel (Ranunculaceae). Nordic Journal of Botany 33: 548-554. DOI: https://doi.org/10.1111/njb.00900

El Mokni, R., Domina, G., Sebei, H. \& El Aouni, M. H. 2014: Hyacinthoides kroumiriensis sp. nov. (Hyacinthaceae): a new species from North West of Tunisia. - International Journal of Advanced Research (IJAR) 2 (9): 640-644.
El Mokni, R., Domina, G., Sebei, H. \& El Aouni, M. H. 2015a: Taxonomic notes and distribution of taxa of Orobanche gr. Minor (Orobanchaceae) from Tunisia. - Acta Botanica Gallica: Botany Letters 162: 5-10. DOI: https://doi.org/10.1080/12538078.2014.993424

El Mokni, R., El Mahmoudi, M. R. \& El Aouni, M. H. 2010: Neottia nidus-avis (L.) L.C.Rich. : une nouvelle orchidée pour la flore de la Tunisie. Lorchidophile 41 (3): 181-187.

El Mokni, R., Elaissi, A. \& Verloove, F. 2019b: New succulents for the Tunisian and North African alien flora. Haseltonia 26: 68-77.

El Mokni, R., Sebei, H. \& El Aouni, M. H. 2015b: Rediscovery of a rare North African endemic Odontites (Orobanchaceae): first record and variability from Tunisia. International Journal of Advanced Research (IJAR) 3: 376-382.

El Mokni, R., Verloove, F., Guiggi, A. \& El Aouni, M. H. 2020: New records of cacti (Opuntioideae \& Cactoideae, Cactaceae) from Tunisia. Bradleya 38: 35-50.

Esler, A. E., Astridge, S. J. 1987: The naturalisation of plants in urban Auckland, New Zealand. 2. Records of introduction and naturalisation. New Zealand Journal of Botany 25 (4): 523-537.

Felger, R. S. \& Joyal, E. 1999: The palms (Arecaceae) of Sonora, Mexico. Aliso: A Journal of Systematic and Evolutionary Botany 18 (1): $1-18$.

Flora of China Editorial Committee. 2016: Flora of China. St. Louis, Missouri and Cambridge, Massachusetts, USA: Missouri Botanical Garden and Harvard University Herbaria. http://www.efloras.org/ flora_page.aspx?flora_id $=2$

Fonseca, S. O. 1999: Diversity and Ecology of Mexican Palms and their Exploitation. Acta Horticulturae 486: 59-63.

GBIF database. 2020: Global Biodiversity Information Facility. Species Occurrence. Livistona chinensis (Jacq.) R.Br. ex Mart., Phoenix canariensis $\mathrm{H}$. Wildpret, Phoenix reclinata Jacq., Phoenix theophrasti Greuter., Washingtonia robusta H.Wendl., viewed on 06 April 2020, from https://www.gbif.org/species/2733469

Gilman, E. F. \& Watson, D. G. 1994: Phoenix canariensis Canary Island Date Palm. US Forest Service, Southern Group of State Foresters: Fact Sheet ST-439.

Govaerts, R. 2016: World Checklist of Arecaceae. London, UK: Royal Botanic Gardens, Kew, viewed on 04 April 2020, from http://apps. kew.org/wcsp/

Govaerts, R. \& Dransfield, J. 2005: World Checklist of Palms: 1-223. The Board of Trustees of the Royal Botanic Gardens, Kew.

Govaerts, R. \& Dransfield, J., Zona, S., Hodel, D. R. \& Henderson, A. 2020: World Checklist of Arecaceae. Facilitated by the Royal Botanic Gardens, Kew, viewed on 04 April 2020, from http://wcsp. science.kew.org/

Greuter, W. 1967 : Beiträige zur Flora der Südägäis 8-9. Bauhinia 3: 243-254.

Hequet, V., Le Corre, M., Rigault, F. \& Blanfort, V. 2009 : Les Espèces Exotiques Envahissantes de Nouvelle-Calédonie. IRD, AMAP, Nouméa, pp. 1-87. http://horizon.documentation.ird.fr/exl-doc/pleins_textes/ divers12-08/010052239.pdf 
Hodel, D. R. 2014: Washingtonia $\times$ filibusta (Arecaceae: Coryphoideae), a new hybrid from cultivation. Phytoneuron 68:1-7.

Horikawa, Y. 1972: Atlas of Japanese Flora. Gakken, Tokyo.

Iamonico, D. \& El Mokni, R. 2018: Amaranthus tunetanus (Amaranthaceae), a new species from Tunisia and a diagnostic key to the North African taxa in subgen. Albersia. South African Journal of Botany 114: 78-83. DOI: https://doi.org/10.1016/j.sajb.2017.10.011

Institute for Regional Conservation. 2016: Floristic Inventory of South Florida Database Online Washingtonia robusta H. Wendl. Desert palm, Washington fan palm. Delray Beach, FL: Institute for Regional Conservation, viewed on 04 April 2020, from http://regionalconservation.org/ircs/database/plants/PlantPage. asp?TXCODE=Washrobu.

IPNI. 2020: International Plant Names Index. Published on the Internet http://www.ipni.org, The Royal Botanic Gardens, Kew, Harvard University Herbaria \& Libraries and Australian National Botanic Gardens. [accessed 07 June 2020].

Jones, D. L. 1995: Palms Throughout the World. Smithsonian Institution Press, Washington, DC.

Kairo, M. A. B., Cheesman, O., Haysom, K. \& Murphy, S. 2003: Invasive Species Threats in the Caribbean Region. CAB International, Trinidad \& Tobago. Unpublished report to the Nature Conservancy, pp. 1-132.

Martin, T. 2009: Naturalisation of Mexican fan palm (Washingtonia robusta) in Auckland. Auckland Botanical Society Journal 64 (2): $145-148$.

McCurrach, J. C. 1960: Palms of the World. New York, NY: Harper and Brothers.

Meyer, J. Y., Lavergne, C. \& Hodel, D. R. 2008: Time Bombs in Gardens: Invasive Ornamental Palms in Tropical Islands, with Emphasis on French Polynesia (Pacific Ocean) and the Mascarenes (Indian Ocean). Palms 52 (2): 71-83. http://www.palms.org

Minnich, R. A., Franco-Vizcaíno, E. \& Salazar-Ceseña, M. 2011: Distribution and Regional Ecology of Californian Palm Oases Interpreted from Google Earth Images. Aliso: A Journal of Systematic and Evolutionary Botany 29 (1): 1-12.

Moore, H. E. \& Guého, L. J. 1984: Famille 189. Palmiers. In: Bosser, T. L., Cadet, J., Guého, J. \& Marais W. (ed.), Flore des Mascareignes. The Sugar Industry Research Institute, Mauritius, ORSTOM, Paris, and the Royal Botanic Gardens, Kew.

Morici, C. 1998: Phoenix canariensis in the wild. Principes 42: 85-89, 92-93.

Oppenheimer, H. L. \& Bartlett, R. T. 2002: New plant records from the main Hawaiian Islands. Bishop Museum Occasional Papers 69 (2): $1-14$.

PIER, 2016: Pacific Islands Ecosystems at Risk. Honolulu, USA: HEAR, University of Hawaii, from http://www.hear.org/pier/index.html

Pooley, E. 1993: The complete guide to trees of Natal, Zululand and Transkei. Durban, South Africa, Natal Flora Publications Trust.

Pyšek, P., Richardson, D. M., Rejemánek, M., Webster, G. L., Williamson, M. \& Kischner, J. 2004: Alien plants in checklist and floras: towards better communication between taxonomist and ecologist. Taxon 53 (1): 131-143.
Richardson, D. M. \& Pyšek, P. 2006: Plant invasion: merging the concepts of species invasiveness and community invasibility. Progress in Physical Geography 30: 409-431.

Rivera, D., Obón, C. Alcaraz, F., Egea, T. Carreño, E., Laguna, E., Santos, A. \& Wildpret, W. 2013: A review of the nomenclature and typification of the Canary Islands endemic palm, Phoenix canariensis (Arecaceae). Taxon 62 (6): 1275-1282.

Santos Guerra, A. 1994: Distribution of Phoenix canariensis in the Canary Islands. - Acta Horticulturae [ed. by Demattê MESP], pp. 71-72.

Spennemann, D. H. R. 2018: Geographical distribution of four key ornamental and production palm species Phoenix canariensis, P. dactylifera, Washingtonia filifera and W. robusta. Albury, NSW: Institute for Land, Water and Society, Charles Sturt University.

Starr, F., Starr, K. \& Loope, L. 2003: Washingtonia spp. Mexican fan palm and California fan palm, Arecaceae. USGS-BRD, Haleakala Field Station, Maui, Hawai'i. Unpublished report, pp. 1-5.

Stevens, P. F. 2012: Angiosperm Phylogeny Website. St Louis, Missouri, USA: University of Missouri and Missouri Botanical Garden, from http://www.mobot.org/MOBOT/research/APweb/

Stevenson, D., Davis, J., Freudenstein, J., Hardy, C., Aimmons, M. \& Specht, C. 2000: A phylogenetic analysis of the monocots based on morphological and molecular character sets, with comments on the placement of Acorus and Hydatellaceae, pp. 17-24. In K. L. Wilson and D. A. Morrison (ed.), Monocots: systematics and evolution. CSIRO Publishing, Collingwood, Victoria, Australia.

Strahm, W. 1993: The conservation and restoration of the flora of Mauritius and Rodrigues. University of Reading. Unpublished PhD thesis, pp. 1-240.

Suzuki, K. 1982: Livistona chinensis var. subglobosa, pp. 124-126. In: Miyazaki, A. (ed.), Flora of Japan. Shibundo, Toyko.

The Plant List. 2020: Version 1.1. Published on the Internet; http:// www.theplantlist.org/ [accessed 07 June 2020].

Tropicos. 2020: Arecaceae. Tropicos.org. Missouri Botanical Garden. Available at http://legacy.tropicos.org/Name/42000339 [accessed 07 June 2020].

Turner, R. J. Jr. \& Wasson, E.1997: Botanica. Mynah, USA.

Tutin, T. G., Heywood, V. H., Burges, N. A., Moore, D. M., Valentine, D. H., Walters, S. M. \& Webb, D. A. (ed.) 1980: Flora Europaea, Vol. 5, pp. 267-268. Cambridge: Cambridge University Press.

Uhl, N. W. \& Dransfield, J. 1987: Genera Palmarum: A classification of palms based on the work of Harold E. Moore, Jr. Allen Press, Lawrence, Kansas.

Uhl, N. W. \& Dransfield, J. 1988: Genera palmarum: a classification of palms based on the work of Harold E. Moore, Jr. (book review). South African Journal of Botany 54 (5): 511-513.

Uhl, N. W. \& Dransfield, J. 1999: Genera Palmarum after ten years. Memoirs of the New York Botanical Garden 83: 245-253.

USDA-ARS, 2016: Germplasm Resources Information Network (GRIN). Online Database. Beltsville, USA: National Germplasm Resources Laboratory, viewed on 04 April 2020, from https:// npgsweb.ars-grin.gov/gringlobal/taxon/taxonomysearch.aspx 
Verloove, F. 2013: New xenophytes from Gran Canaria (Canary Islands, Spain), with emphasis on naturalized and (potentially) invasive species. Collectanea Botanica 32: 59-82. DOI: http://dx.doi. org/10.3989/collectbot.2013.v32.006

Wagner, W. L., Herbst, D. R. \& Sohmer, S. H. 1999: Manual of the flowering plants of Hawai'i, Vols. 1 \& 2, In: Manual of the flowering plants of Hawai'i, Vols. $1 \&$ 2. University of Hawai'i Press/Bishop Museum Press. $1918+[1] \mathrm{pp}$.

Wicht, H. 1969: The indigenous palms of southern Africa. Cape Town, Howard Timmins.

Yoshida, N., Nobe, R., Ogawa, K. \& Murooka, Y. 2000: Origin of Livistona chinensis var. subglobosa (Arecaceae) on the "Islet of the Gods”: Aoshima, Japan. American Journal of Botany 87: 1066-1067.

Zeddam, A. \& Raus, Th. 2016: Washingtonia robusta H.Wendl. Pp. 434-435 in: Raab-Straube E. von \& Raus Th. (ed.), Euro+MedChecklist Notulae, 6 [Notulae ad floram euromediterraneam pertinentes No. 35]. Willdenowia 46: 423-442. DOI: http://dx.doi. org/10.3372/wi.46.46310 